\title{
ANALISIS TINGKAT IMPLMENTASI SMK3 PADA KONSTRUKSI BANGUNAN DI SURABAYA BERDASARKAN PP NO 50 TAHUN 2012
}

\author{
Siti Choiriyah" ${ }^{1)}$, Feri Harianto1), dan Dian Henggar'1) \\ 1) Jurusan Teknik Sipil, Institut Teknologi Adhi Tama Surabaya, Jawa Timur \\ siti.choiriyah@itats.ac.id
}

\begin{abstract}
The development of construction project brings positive effects to the manpower absorption and development equalization. Unfortunately, construction activity also has risks such as a high occupational accident. This research aimed at describing the success level for implementing SMK3 (Sistem Managemen Keselamatan dan Kesehatan Kerja or Occupational Health and Safety Management System at the building construction in Surabaya, particularly at the buildings of Super Mall Pakuwon and Telkom Group Surabaya based on PP No. 50 in 2012. The success percentage of SMK3 was determined by the qualitative method using data analyses through a checklist and interview. Both projects of Super Mall Pakuwon Surabaya and Telkom Group Surabaya were in the satisfactory category by $90.18 \%$ and $98.26 \%$ respectively. Moreover, the results of the triangulation method indicated that the three themes and sub-themes of both projects concluded the importance of occupational safety and the effectiveness of K3 protection which is planned, measurable, structured, and integrated.
\end{abstract}

Keywords: SMK3, check list, interview

\begin{abstract}
ABSTRAK
Pembangunan proyek konstruksi berdampak positif terhadap penyerapan tenaga kerja dan pemerataan pembangunan, tetapi sisi lain kegiatan konstruksi memiliki resiko terjadinya kecelakaan kerja yang tinggi. Tujuan penelitian ini yaitu mendeskripsikan tingkat keberhasilan implementasi SMK3 pada konstruksi bangunan di Surabaya, khususnya Super Mall Pakuwon dan Gedung Telkom Group Surabaya berdasarkan PP No 50 Tahun 2012. Penentuan prosentase keberhasilan SMK3 menggunakan metode kualitatif dengan analisis datanya menggunakan check list dan wawancara. Pada proyek Super Mall Pakuwon Surabaya menunjukkan kategori memuaskan dengan prosentase mencapai 90.18\%, sedangkan pada proyek gedung Telkom Group Surabaya prosentase penerapannya mencapai $98.26 \%$ yang juga menunjukkan kategori yang memuaskan. Dengan metode triangulasi diketahui bahwa ketiga tema dan sub tema pada kedua proyek mengarah pada satu kesimpulan yaitu pentingnya keselamatan kerja pada proyek sekaligus meningkatkan efektifitas perlindungan K3 yang terencana, terukur, terstruktur, dan terintegrasi.
\end{abstract}

Kata kunci: SMK3, Check list, Wawancara 


\section{PENDAHULUAN}

Pembangunan proyek konstruksi merupakan salah satu kegiatan yang memiliki risiko terjadinya kecelakaan kerja yang cukup tinggi. Apabila bahaya tersebut tidak dicegah, maka memerlukan biaya yang lebih besar dalam pemberian kompensasi bagi pekerja yang mengalami kecelakaan. Langkah untuk mencegah terjadinya risiko tersebut, maka diperlukan sistem manajemen K3 (SMK3) yang tertuang pada PP No. 50 Tahun 2012.

SMK3 bertujuan untuk meningkatkan efektifitas perlindungan $\mathrm{K} 3$ yang terencana, terukur, terstruktur, dan terintegrasi; mencegah dan mengurangi kecelakaan kerja dan penyakit akibat kerja dengan melibatkan unsur manajemen, pekerja, dan atau serikat pekerja, serta menciptakan tempat kerja yang aman, nyaman, dan efisien untuk mendorong produktivitas (PP No. 50 Tahun 2012). Maka, saat pelaksanaan konstruksi wajib menerapkan SMK3 di lokasi kerja karena masalah keselamatan dan kesehatan bagian dari perencanaan dan pengendalian proyek (Cahya, 2015). Fungsi lain dari SMK3 untuk mengukur pencapaian K3 dalam organisasi, sebagai acuan pengembangan SMK3 dalam organisasi, dan sebagai dasar pemberian awards atas pencapaian K3 (Ramli, 2010).
Tujuan dari penelitian ini adalah mendeskripsikan tingkat keberhasilan implementasi SMK3 pada konstruksi bangunan di Surabaya, khususnya Super Mall Pakuwon dan Gedung Telkom Group Surabaya berdasarkan PP No 50 Tahun 2012.

\section{KAJIAN PUSTAKA}

\subsection{Pengertian Sistem Manajemen K3}

Sistem manajemen K3 merupakan bagian dari seluruh manajemen melalui proses yang matang guna memenuhi kebutuhan bagi pengembangan, penerapan, pencapaian, dan pengkajian kebijakan secara efisien dan produktif. Hal ini sesuai dengan PP No. 50 Tahun 2012 Pasal 1 Ayat 1, yang berbunyi: "Sistem Manajemen K3 (SMK3) adalah bagian dari sistem manajemen perusahaan secara keseluruhan dalam rangka pengendalian risiko yang berkaitan dengan kegiatan kerja guna terciptanya tempat kerja yang aman, efisien dan produktif.

\subsection{Manfaat SMK3}

Berkaitan dengan manfaat SMK3, Ramli (2010) menjelaskan beberapa fungsi dari SMK3 yaitu:

1. Untuk mengukur pencapaian $\mathrm{K} 3$ dalam organisasi;

2. Sebagai acuan pengembangan SMK3 dalam organisasi; 
3. Sebagai dasar pemberian penghargaan (awards) atas pencapaian $\mathrm{K} 3$;

4. Sebagai sertifikasi.

\subsection{Penilaian PP No 50 Tahun 2012}

Penilaian dilakukan melalui audit SMK3 sesuai dengan PP No. 50 Tahun 2012 seperti pada tabel berikut:

\section{Tabel 1. Tingkat Pencapaian SMK3}

\begin{tabular}{|c|c|c|c|}
\hline \multirow{2}{*}{$\begin{array}{c}\text { Kategori } \\
\text { Perusahaan }\end{array}$} & \multicolumn{3}{|c|}{ Tingkat Pencapaian Penerapan } \\
\hline & $0-59 \%$ & $60-84 \%$ & $85-100 \%$ \\
\hline $\begin{array}{l}\text { Kategori } \\
\text { tingkat awal } \\
\text { (64 kriteria) }\end{array}$ & Kurang & Baik & Memuaskan \\
\hline $\begin{array}{l}\text { Kategori } \\
\text { tingkat } \\
\text { transisi (122 } \\
\text { kriteria) }\end{array}$ & Kurang & Baik & Memuaskan \\
\hline $\begin{array}{l}\text { Kategori } \\
\text { tingkat } \\
\text { lanjutan } \\
(166 \\
\text { kriteria) }\end{array}$ & Kurang & Baik & Memuaskan \\
\hline
\end{tabular}

Sumber: Anonim, 2012

1. Kategori kritikal, yaitu temuan yang mengakibatkan fatality atau kematian.

2. Kategori mayor, yaitu:

a. Tidak memenuhi ketentuan peraturan perundangundangan;

b. Tidak melaksanakan salah satu prinsip SMK3; c. Terdapat temuan minor untuk satu kriteria audit di beberapa lokasi.

3. Sedangkan untuk kategori minor, yaitu ketidakkonsistenan dalam pemenuhan persyaratan perundang-undangan, standar, pedoman, dan acuan lainnya.

\section{METODE PENELITIAN}

Metode yang digunakan adalah metode kualitatif, dan pengambilan datanya dengan survey dengan instrument kuesioner check list dan wawancara.

Kuesioner berisikan pertanyaan sesuai dengan PP No. 50 Tahun 2012 dengan kategori jawaban sesuai, minor, mayor, dan kritikal. Uji validitas menggunakan validitas konseptual, yakni berdasarkan teori/peraturan yang sudah ditetapkan dari PP No 50 Tahun 2012. Alasan lain menggunakan validitas konseptual yaitu tiap bab dalam kuesioner (check list) tidak dapat diuji valid tidaknya karena telah menjadi peraturan yang sudah ditetapkan. Pengumpulan data menggunakan kuesioner dengan instrumen check list tidak perlu menggunakan uji reliabilitas, karena kuesionernya tidak dikembangkan sendiri, melainkan berasal dari peraturan check list SMK3 pada PP No 50 Tahun 2012. 
Pengertian reliabilitas itu sendiri adalah ketepatan alat ukur memperoleh hasil yang stabil, dapat diandalkan (dependability), diramalkan (predictability) secara akurat dan dilakukan berulang-ulang (konsisten)dari responden yang beragam (Pujihastuti, 2010). Perhitungan check listnya adalah:

Persentase Tingkat Pencapaian = $\frac{\sum \text { Nilai Pemenuhan }}{166 \text { Kriteria }} \times 100$

Teknik wawancara yang digunakan adalah wawancara secara terstruktur (structural interview), yakni teknik pengumpulan data yang telah mengetahui dengan pasti tentang informasi apa yang akan diperoleh (Sugiyono, 2009). Tipe wawancara yang digunakan adalah tipe wawancara terstruktur, yaitu membuat daftar pertanyaan secara rapi dengan urutan yang ideal terlebih dahulu dan kemudian menanyakan pada narasumber mengikuti alur daftar pertanyaan yang telah dibuat (Soeherman, 2019). Untuk pengelolaan datanya menggunakan triangulasi dengan satu metode dari berbagai objek yang berbeda yakni dengan melakukan wawancara pada lebih dari satu narasumber, atau mengamati beberapa objek yang saling terkait untuk memastikan kebenaran satu kejadian/keadaan. (Soeherman, 2019).

\section{HASIL DAN PEMBAHASAN}

\subsection{Tingkat Awal}

\subsubsection{Proyek Super Mall Pakuwon}

Hasil check list yang diperoleh dari proyek tersebut adalah:

1. Total sesuai: 56 kriteria.

2. Total tidak sesuai: 8 kriteria.

3. Tingkat pencapaian: $\frac{56}{64} \times 100 \%=87.50 \%$.

4. Ketidaksesuaian: $12.50 \%$.

5. Tingkat penerapan: memuaskan.

\subsubsection{Proyek Telkom Group Surabaya}

Hasil check list yang diperoleh proyek Telkom Group Surabaya sebagai berikut:

1. Total sesuai: 63 kriteria.

2. Total tidak sesuai: 1 kriteria.

3. Tingkat pencapaian: $\frac{63}{64} \times 100 \%=98.43 \%$.

4. Ketidaksesuaian: $1.56 \%$.

5. Tingkat penerapan: memuaskan.

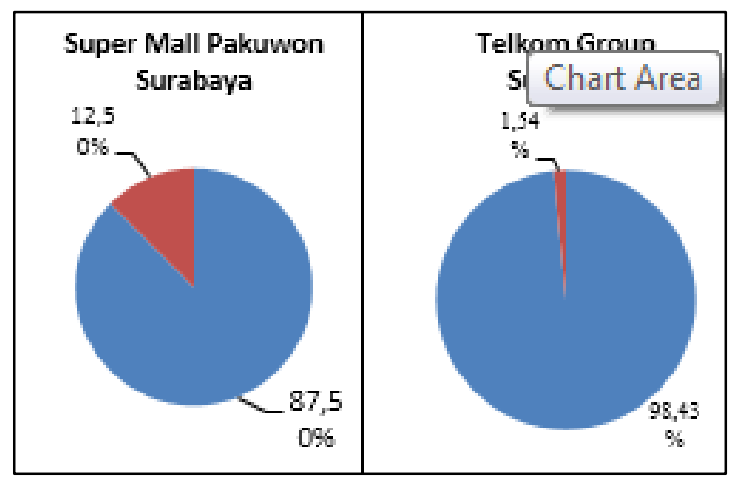

Gambar 1. Prosentase Tingkat Awal 
Pada Gambar 1 dijelaskan bahwa prosentase tingkat pencapaian pada proyek Super Mall Pakuwon sebesar Prosentase tingkat pencapaian ada $87.50 \%$ dan ketidaksesuaiannya $12.50 \%$. Dan pada proyek Telkom Group Surabaya sebesar 98.43\% dan prosentase ketidaksesuaian hanya $1.56 \%$. Berdasarkan hasil penilaian tingkat awal pada kedua proyek termasuk tingkat penilaian penerapan memuaskan menurut PP No 50 Tahun 2012.

\subsection{Tingkat Transisi}

\subsubsection{Proyek Super Mall Pakuwon}

Hasil check list yang diperoleh dari proyek Super Mall Pakuwon adalah:

1. Total sesuai: 46 kriteria.

2. Total tidak sesuai: 12 kriteria.

3. Tingkat pencapaian: $\frac{110}{122} \times 100 \%=90.16 \%$.

4. Ketidaksesuaian: $9.83 \%$.

5. Tingkat penerapan: memuaskan.

\subsubsection{Proyek Telkom Group Surabaya}

Hasil check list yang diperoleh dari proyek Telkom Group Surabaya adalah:

1. Total sesuai: 55 kriteria.

2. Total tidak sesuai: 3 kriteria.

3. Tingkat pencapaian: $\frac{120}{122} \times 100 \%=97.54 \%$.

4. Ketidaksesuaian: $2.45 \%$.

5. Tingkat penerapan: memuaskan.

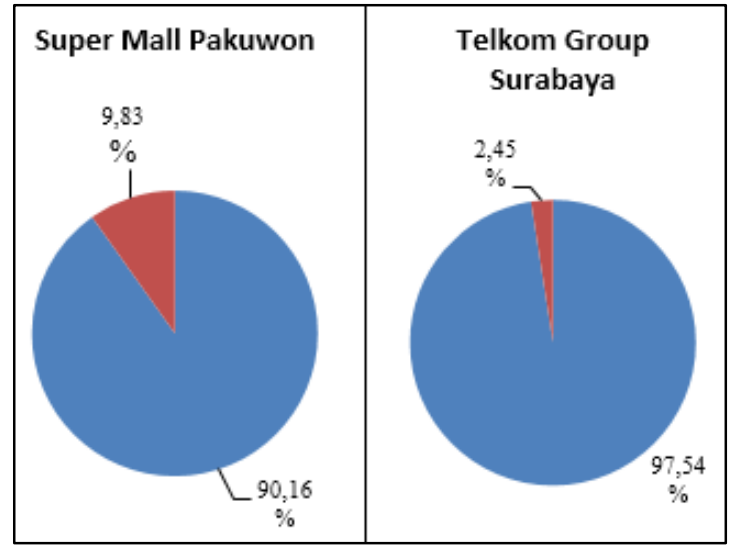

Gambar 2. Prosentase Tingkat Transisi

Pada Gambar 2 menunjukkan prosentase tingkat pencapaiannya sebesar $90.16 \%$ dan ketidaksesuaiannya $9.83 \%$. Sedangkan pada proyek Telkom Group Surabaya sebesar $97.54 \%$ dan prosentase ketidaksesuaian sebesar $2.45 \%$. Berdasarkan hasil penilaian tingkat awal pada kedua proyek termasuk tingkat penilaian penerapan memuaskan menurut PP No 50 Tahun 2012.

\subsection{Tingkat Lanjutan}

\subsubsection{Proyek Super Mall Pakuwon}

Hasil check list yang diperoleh dari proyek Super Mall Pakuwon adalah:

1. Total sesuai: 32 kriteria.

2. Total tidak sesuai: 12 kriteria.

3. Tingkat pencapaian: $\frac{154}{166} \times 100 \%=92.77 \%$.

4. Ketidaksesuaian: $7.22 \%$.

5. Tingkat penerapan: memuaskan. 


\subsubsection{Proyek Telkom Group Surabaya}

Hasil check list yang diperoleh dari proyek Super Mall Pakuwon adalah:

1. Total sesuai: 42 kriteria.

2. Total tidak sesuai: 2 kriteria.

3. Tingkat pencapaian: $\frac{164}{166} \times 100 \%=98.79 \%$.

4. Ketidaksesuaian: $1.20 \%$.

5. Tingkat penerapan: memuaskan.

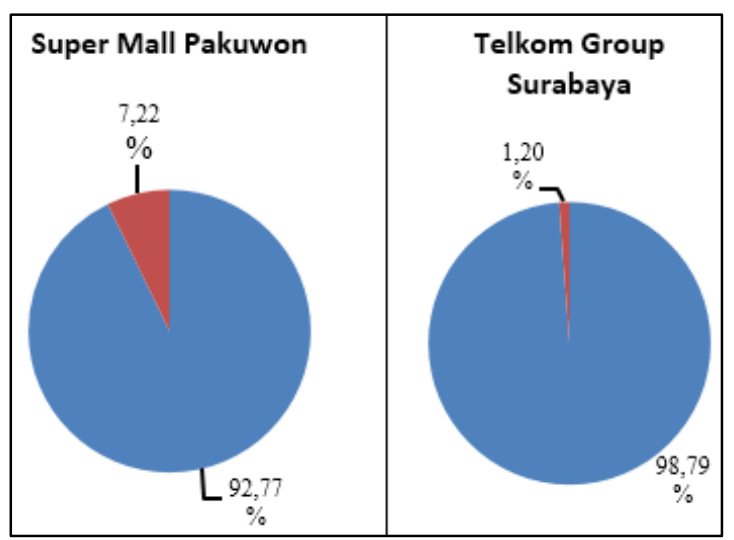

Gambar 3. Prosentase Tingkat Awal

Pada Gambar 3 menunjukkan tingkat pencapaiannya sebanyak $92.77 \%$ dan ketidaksesuaiannya sebesar $7.22 \%$. pada proyek Super Mall Pakuwon dan pada proyek Telkom Group Surabaya prosentase tingkat pencapaian sebesar 98.79\% dan prosentase ketidaksesuaian sebesar $1.20 \%$.

\subsection{Analisis Wawancara}

Dari hasil wawancara pada kedua pihakyakni pihak site manager dari proyek Super Mall Pakuwon dan Telkom Group Surabaya dapat disimpulkan dari segi kebijakan penerapan sistem manajemen K3 sudah berjalan dari awal pembangunan dan diberlakukan wajib, sehingga diberikan sanksi bagi para pekerja yang tidak memenuhi penerapan sistem manajemen K3. Pekerja yang tidak patuh akan dikenakan sanksi teguran, denda cash, hingga pemecatan. Ada beberapa faktor dalam pelaksanaan penerapan sistem manajemen K3 yaitu terkendala oleh tenaga kerja yang kurang sadar dan menyepelekan penerapa K3. Hal tersebut mengakibatkan kecelakaan kerja seperti terkena paku dan terbentur terjadi, sehingga mengakibatkan korban kecelakaan dari awal sampai saat ini kurang lebih sekitar 30 pekerja. Pada proyek Super Mall Pakuwon dan Telkom Group Surabaya telah diberikan jaminan kecelakaan.

Validasi menggunakan triangulasi dapat diketahui bahwa hasil wawancara dengan ketiga site manager dengan orang, waktu, dan ruang yang berbeda namun hasilnya mendekati sama. Dalam triangulasi juga dapat diketahui bahwa ketiga tema dan beberapa sub tema mengarah pada suatu kesimpulan yaitu pentingnya keselamatan kerja pada proyek. 


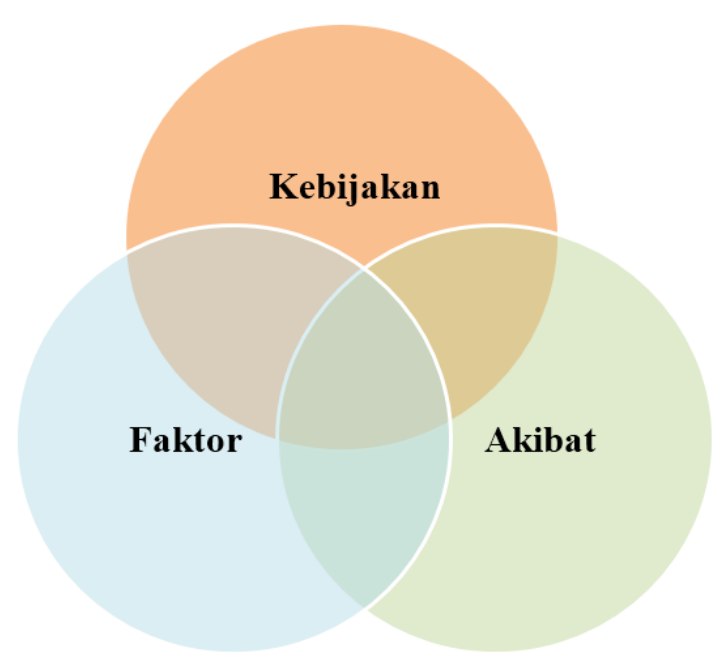

\section{Gambar 4. Penegakan Validitas Menggunakan Triangulasi Data}

\section{SIMPULAN}

Berdasarkan penelitian yang telah dilaksanakan, maka dapat disimpulkan bahwa:

1. Proyek pembangunan Super Mall Pakuwon Surabaya sudah menerapkan Sistem Manajemen K3, namun masih belum mencapai $100 \%$. Berdasarkan PP Nomor 50 Tahun 2012 menunjukkan prosentase penerapan yang mencapai 90.14\% pada proyek Super Mall Pakuwon Surabaya, sedangkan pada proyek Telkom Group Surabaya prosentase penerapannya mencapai $98.25 \%$ dan kedua proyek pembangunan tersebut dikategorikan tingkat penerapan memuaskan.
2. Hasil penegakan validitas menggunakan triangulasi hasilnya dapat diketahui bahwa hasil wawancara dengan ketiga responden K3 dan dengan orang, waktu, dan ruang yang berbeda hasilnya menyerupai.

\section{DAFTAR PUSTAKA}

Anonim. (2012). Peraturan Pemerintah Republik Indonesia Nomor 50 Tahun 2012 Tentang Penerapan Sistem Manajemen K3. Jakarta: Kementrian Sekretariat Negara RI.

Pujihastuti, I. (2010). Prinsip Penulisan Kuesioner Penelitian. Jurnal Agribisnis dan Pengembangan Wilayah CEFARS.

Ramli, S. (2010). Sistem Manajemen Keselamatan \& Kesehatan Kerja. Jakarta: Dian Rakyat.

Sugiyono. (2009). Memahami Penelitian Kualitatif. Bandung: ALFABETA

Soeherman, B. (2019). Fun Research Pemilihan Kualitatif dengan Design Thinking. Jakarta: KOMPAS GRAMEDIA

Wulandani, CD., Wardani, MK., \& Harianto, F. (2015). Evaluasi Penerapan Sistem Manajemen Keselamatan dan Kesehatan Kerja (SMK3) pada Proyek Pembangunan Apartemen Gunawangsa MERR Surabaya. 